\section{Техногенное воздействие автомобильных дорог на экосистемы придорожной полосы}

\author{
3. Н. Нахаев ${ }^{1}$ \\ Воронежская государственная лесотехническая \\ академия
}

\begin{abstract}
АННОТАЦИЯ
В статье исследуется техногенное воздействие автомобильных дорог на экосистемы придорожной полосы с точки зрения системного анализа, которое следует рассматривать как взаимоотношение двух различающихся по закономерностям развития систем: технической системы «автомобильная дорога» и экологической системы придорожной полосы.
\end{abstract}

Ключевые слова: техногенное воздействие, придорожная полоса, система «автомобильная дорога», экологическая система.

\section{SUMMARY}

The article deals with technological influence of motorways on the ecosystems of the roadside from the point of view of systematic analysis, that should be considered as an iterrelation of two different in development regularities systems: technical system "motorway" and ecological system of the roadside.

Keywords: technological influence, the roadside, "motorway" system, ecological system.

Техническая система «автомобильная дорога» состоит из двух взаимосвязанных подсистем - «поток автомобилей» и «дорожное сооружение», при этом подсистема «дорожное сооружение» играет роль регулятора другой подсистемы «транспортный поток».

Экосистема (экологическая система) - природная функциональная система, образованная взаимосвязанными сообществом живых организмов и средой их обитания [1].

Экосистема (геобиоценоз) состоит из подсистемы неживой природы - экотопа, включающего атмосферу, почву, гидросферу, и подсистемы живой природы - биоценоза, включающего фитоценоз (продуценты), зооценоз (консументы) и микробиоценоз (редуценты). В естественных условиях экосистема обеспечивает прирост органического вещества за счет процессов фотосинтеза, его использование животными и минерализацию остатков редуцентами. Элементы биоценоза могут образовать популяцию - совокупность особей (растений, животных, микроорганизмов), населяющих определенную территорию и в той

\footnotetext{
${ }^{1}$ Автор - соискатель кафедры транспорта и инже-
} нерной геодезии

(C) 3. Н. Нахаев, 2003 или иной мере изолированных от других таких же совокупностей [1].

С точки зрения системного анализа можно выделить прямое и косвенное техногенное воздействие технической системы «автомобильная дорога» на экосистемы придорожной полосы [2].

Прямое воздействие заключается в изъятии части экосистемы под дорожные сооружения с полным уничтожением почвенного и растительного покрова и изменении водного режима грунтов. Обычно такое воздействие осуществляется в процессе строительства или реконструкции автомобильной дороги и приводит к значительной трансформации экосистемы в результате разрыва многочисленных связей между экотопом и биоценозом. Детальный анализ такого воздействия требует отдельного рассмотрения естественных процессов в экосистемах, их способности к компенсации причиненного вреда.

Косвенное воздействие на биоценоз осуществляется через биотоп путем физического и химического воздействия потока автотранспорта, дорожных сооружений и эксплуатационной деятельности.

Физическое воздействие представляет собой перенос пыли с поверхности дороги и обочин, шумовое, вибрационное, электромагнитное и радиоактивное воздействие.

Пыль на поверхности дорожного покрытия представляет собой продукты износа дорожной одежды и накопления минеральных частиц в периоды между выпадением осадков. В составе пыли более $30 \%$ coставляют мелкие частицы размером менее 100 мкм $[2,3,4]$, которые свободно переносятся воздушными потоками в придорожную полосу и там оседают. Часть крупных и мелких частиц с поверхности проезжей части и обочин переносится в придорожную полосу водными потоками.

Шумовое воздействие в условиях современного транспортного потока сильно влияет на животный мир и человека. Современные поршневые двигатели внутреннего сгорания в автомобилях и дорожностроительных машинах при работе на номинальном режиме излучают 2-3 Вт акустической мощности, что приводит к уровню шума 104-120 дБ на расстоянии $1 \mathrm{м}$ от двигателя. С расстоянием величина шума уменьшается. Действие шума на экосистемы не носит необратимого характера и по его прекращении связи в биоценозах могут быть восстановлены. Аналогичное действие на экосистемы оказывает вибрация, однако зона ее действия мала и даже для крупных магистралей не превышает ширины резервнотехнологической полосы.

Источником электромагнитного излучения являются линии электропередач и системы электрооборудования транспортных средств. Действие этого вида излучения на экосистемы представляет опасность только в отдельных местах, где отмечается сосредо- 
точение источников данного излучения, и оно может быть нейтрализовано эффективными методами защиты [2].

Особую опасность для экосистем придорожной полосы представляет радиоактивное излучение. Оно вызывает необратимые генетические изменения в живых организмах. Источником его могут быть материалы, входящие в состав дорожной одежды, щебень, песок, а также внешние факторы, связанные с авариями на атомных объектах. Радиоактивность от материалов, входящих в состав дорожной одежды, как правило, не представляет опасности для экосистем.

Химическое воздействие является основным на стадии эксплуатации автомобильной дороги и представляет собой перенос воздушным и водным путем вредных и токсичных веществ, образующихся в результате химических реакций при горении углеводородных топлив в двигателях внутреннего сгорания, а также накопление в придорожной полосе веществ, используемых при летнем и зимнем содержании дорог.

Вредные и токсичные вещества, содержащиеся в отработавших газах двигателей, разделяются на три группы:

1) углеродсодержащие вещества - продукты полного и неполного сгорания топлив: $\mathrm{CO}_{2}, \mathrm{CO}$, углеводороды ( в т.ч. и полициклические ароматические), сажа;

2) вещества, образование которых не связано с горением топлива (оксиды азота);

3) вещества, выброс которых связан с примесями, содержащимися в топливе (соединения серы, свинца и других тяжелых металлов), воздухе (кварцевая пыль, аэрозоли), а также образующимися в процессе износа металлов (оксиды металлов). Рассмотрим наиболее опасные токсичные вещества, образующиеся при работе автомобильных двигателей и попадающие в придорожную полосу.

Монооксид углерода (угарный газ) - образуется при сгорании углеводородного топлива при недостатке воздуха и при диссоциации $\mathrm{CO}_{2}$. Токсичное действие монооксида углерода на организм человека и теплокровных животных связано с его способностью вступать во взаимодействие с гемоглобином крови. Вызывает расстройство нервной и сердечно-сосудистой систем, обладает кумулятивным эффектом. Максимально допустимая разовая концентрация в соответ-

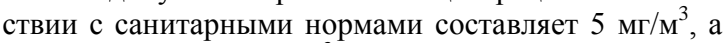

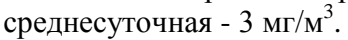

Оксиды азота представляют собой смесь соединений: $\mathrm{N}_{2} \mathrm{O}, \mathrm{NO}, \mathrm{N}_{2} \mathrm{O}_{3}, \mathrm{NO}_{2}, \mathrm{~N}_{2} \mathrm{O}_{4}, \mathrm{~N}_{2} \mathrm{O}_{5}$. Преобладает $\mathrm{NO}$ (99\% в бензиновых и более $90 \%$ в дизельных двигателях). В двигателях внутреннего сгорания основная масса NO образуется при высокотемпературном окислении азота воздуха. В атмосфере NO в течение 0,1 - 10 ч окисляется до $\mathrm{NO}_{2}$.
Диоксид азота отнесен к 2-му классу токсичности (в 41 раз опаснее окиси углерода). Даже в небольшой концентрации он опасен для органов дыхания человека и животных, так как раздражает легкие и дыхательные пути, способствует возникновению воспалительных процессов в них. При высоком содержании действует на нервную систему человека, вызывая головокружение и неадекватные реакции («веселящий газ»). Оказывает вредное воздействие на растения. Предельно допустимая разовая концентрация

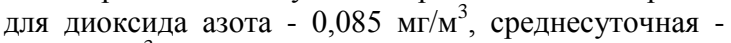
$0,040 \mathrm{Mr} / \mathrm{M}^{3}$.

Углеводороды представляют собой смесь различных низкомолекулярных соединений (метан, пропан, гексан) и альдегидов.

Низкомолекулярные углеводороды не относятся к высокотоксичным соединениям. Однако альдегиды, содержащие кислород, действуют на слизистую оболочку органов дыхания и на нервную систему [5]. Предельно допустимая разовая концентрация углево-

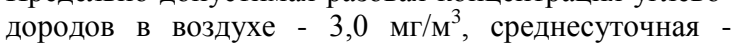
$1,0 \mathrm{M \Gamma} / \mathrm{M}^{3}$.

Диоксид серы (сернистый ангидрид) - $\mathrm{SO}_{2}-$ образуется во время горения содержащегося в топливе соединения серы и входит в состав твердых частиц сажи. В выбросах автомобильных двигателей [6] присутствует в небольших количествах (в основном в дизельных).

Имеет резкий раздражающий запах, хорошо растворяется в воде, образуя сернистую кислоту. Дожди с высоким содержанием сернистой кислоты называют «кислотными». Под действием выпадения этих дождей наблюдается угнетение лесной растительности, изменение состава воды в водоемах и гибель ценных пород рыб.

Диоксид серы раздражает слизистые оболочки глаз и дыхательных путей, вызывает хронические заболевания легких, способствует возникновению хронического гастрита, бронхита, ларингита, рака легких и других болезней. Предельно допустимая разовая

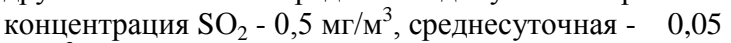
$\mathrm{M \Gamma} / \mathrm{M}^{3}$.

В состав твердых частиц входят нерастворимые (твердый углерод, оксиды металлов, диоксид кремния, сульфаты, нитраты, асфальты, соединения свинца) и растворимые в органическом растворителе (смолы, фенолы, альдегиды, лак, нагар, тяжелые фракции топлива и масел) вещества. Основным компонентом твердых нерастворимых веществ является сажа (твердый углерод). Она образуется при термическом разложении углеводородов в газовой или паровой фазе при недостатке кислорода. Особо опасен процесс выгорания сажи при температуре 850920 К, в ходе которого на поверхности частиц происходит сорбция твердых иглообразных образований. Предельно допустимая концентрация сажи в атмо-

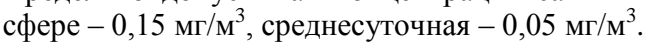


Первое место по выбросам среди тяжелых металлов занимает свинец, присутствующий в виде соединений галогенидов свинца и входящий в состав твердых частиц. Он образуется в результате сгорания бензина, содержащего тетраэтилсвинец, и истирания автопокрышек. Свинец относится к веществам первого класса опасности, вредно действует на костные ткани и кровепроизводящие органы и представляет особую опасность для экосистем, поскольку соединения свинца устойчивы в почве и накапливаются в растительности с последующим переходом по пищевой цепи к домашним животным и человеку. Предельно допустимая разовая концентрация свинца в воздухе составляет $0,0003 \mathrm{Mг} / \mathrm{M}^{3}$, среднесуточная - $0,001 \mathrm{Mг} / \mathrm{M}^{3}$. Исследования $[5,6]$ показали, что $75 \%$ свинца, содержащегося в топливе двигателя внутреннего сгорания, выделяется в виде аэрозолей и рассеивается. Устанавливаются 3 группы фракций, которые различно рассеиваются в придорожной полосе. Первая группа состоит из наиболее тяжелых частиц, которые оседают на расстоянии не более 5-7 м от края проезжей части. Вторая группа состоит из более мелких частиц, которые оседают в полосе до 30-100 м от края проезжей части. Эти отложения наиболее биологически активны, отличаются большой растворимостью и, следовательно, большой токсичностью. Наиболее мелкие частицы третьей фракции (менее 5 мкм) переносятся воздушными течениями на большие расстояния (до 150 км). Соотношение между 1-й, 2-й и 3-й группами в среднем составляет $8 \%, 6 \%, 86 \%$. Основными источниками накопления свинца в пыли являются выбросы сажи из двигателей, работающих на бензине с добавками тетраэтилсвинца, а также истирание автопокрышек.

Общие объемы пылеобразования и выделения токсичных и вредных веществ зависят от интенсивности движения транспортного потока. Чем больше величина транспортного потока, тем больше объемы расхода горючего и объемы выхлопных газов. Однако на интенсивность выделения существенно влияет режим работы автомобильных двигателей. При работе в оптимальном режиме выделение токсичных веществ (эмиссия) в 2-4 раза меньше максимальной (за исключением соединений азота, выбросы которых с увеличением скорости линейно возрастают). Особенно это существенно в населенных пунктах, где наибольшие выбросы отмечаются в местах вынужденной остановки автомобилей, где двигатели работают на «холостом» ходу. В процессе распространения пыли и токсичных газов большое значение имеют условия их воздушного и водного переноса, на которые значительно влияют метеорологические условия: скорость и направления ветра, температура воздуха, режим и количество атмосферных осадков. Кроме того, важную роль в перераспределении токсичных веществ играют конструкция насыпи или выемки, конструкция водоотводящих устройств, рельеф придорожной полосы, наличие лесных полос и их конструкция.

Дальнейшая трансформация загрязняющих веществ и попадание их в различные элементы пищевой цепи зависят от внутренних закономерностей экосистемы: замкнутости циклов переноса вещества, устойчивости растительного и почвенного покрова к загрязнителям. Для экосистем придорожной полосы очень важной характеристикой является их ассимиляционная способность, сокращающая вынос токсичных соединений за пределы придорожной полосы.

Приведенная выше качественная характеристика техногенного воздействия автомобильных дорог позволяет сделать вывод, что для разработки методов прогноза техногенного воздействия и, в частности, химического загрязнения, необходимо иметь математические модели транспортного потока и эмиссии загрязняющих веществ, переноса примесей воздушным и водным путем, осаждения примесей на поверхность почвы и растительность, трансформации загрязняющих веществ внутри почвенного слоя и в растениях.

\section{СПИСОК ЛИТЕРАТУРЫ}

1. Курьянов В. К., Скрыпников А. В. Эксплуатационные документы систем моделирования процессов функционирования дороги в рабочем проекте первой очереди САПР-АД // Рациональное использование лесных ресурсов: Материалы международной научно-практической конференции, посвященной 100-летию со дня рождения В. Е. Печенкина / Под общ. ред. Ю. А. Ширина. Йошкар-Ола, 2001. 205 с.

2. Скрыпников А. В. Методы оценки техникоэкономических, энергетических, экологических показателей функционирования дороги / Воронеж. гос. лесотехн. акад. Деп. в ВИНИТИ 12.03.01. № 616-B2001. 14 c.

3. Курьянов В. К., Афоничев Д. Н., Бурмистрова О. Н., Скрыпников А. В. Повышение транспортно-эксплуатационных качеств автомобильных дорог лесопромышленного комплекса: Монография / Воронеж. гос. лесотехн. акад., Ухтинск. гос. техн. ун-т. Воронеж: Изд-во Воронеж. гос. ун-та, 2002.

4. Курьянов В. К. Повышение транспортноэксплуатационных качеств автомобильных дорог лесопромышленного комплекса: Монография / В. К. Курьянов, Д. Н. Афоничев, О. Н. Бурмистрова, А. В. Скрыпников; Воронеж. гос. лесотехн. акад., Ухтинск. гос. техн. ун-т. Воронеж: Изд-во Воронеж. гос. ун-та, 2002. 176 с.

5. Курьянов В. К., Скрыпников А. В. Современные критерии оценки транспортно-эксплуатационных качеств автомобильных дорог / Воронеж. гос. лесотехн. акад. М., 2000. Деп. в ВИНИТИ 15.03.00, № 648-B00.

6. Курьянов В. К., Скрыпников А. В. Современные этапы развития автомобильного проектирования дорог (САПР-АД) // Математическое моделирование, компьютерная оптимизация технологий, параметров оборудования и систем лесного комплекса: Межвуз. сб. науч. тр. / Под ред. проф. В. С. Петровского / ВГЛТА. Воронеж, 2000. $259 \mathrm{c}$. 